\title{
Contingency, Freedom, and Classical Liberalism
}

Calcaterra and Rorty's Politics

William M. Curtis

\section{OpenEdition}

\section{Journals}

Electronic version

URL: http://journals.openedition.org/ejpap/2193

DOI: 10.4000/ejpap.2193

ISSN: 2036-4091

Publisher

Associazione Pragma

Electronic reference

William M. Curtis, "Contingency, Freedom, and Classical Liberalism », European Journal of Pragmatism and American Philosophy [Online], XII-2 | 2020, Online since 14 December 2020, connection on 15 December 2020. URL : http://journals.openedition.org/ejpap/2193 ; DOI : https://doi.org/10.4000/ ejpap. 2193

This text was automatically generated on 15 December 2020.

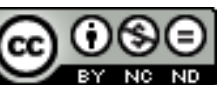

Author retains copyright and grants the European Journal of Pragmatism and American Philosophy right of first publication with the work simultaneously licensed under a Creative Commons AttributionNonCommercial-NoDerivatives 4.0 International License. 


\title{
Contingency, Freedom, and Classical Liberalism
}

\author{
Calcaterra and Rorty's Politics
}

William M. Curtis

1 Rosa Calcaterra has written an extremely learned and thoughtful book about Richard Rorty's controversial neopragmatism. It is a worthy addition to the growing number of works that offer a more generous and balanced assessment of Rorty's thought, in contrast to the scores of highly critical treatments it received during his career. But, as Calcaterra insists, her book is "not an apology for Rorty" (Calcaterra 2019: ix); she critically approaches what she calls Rorty's philosophical "provocations," especially his conceptions of contingency and normativity, to see how they might inspire fresh thinking. Calcaterra examines these provocations by setting them in historical and philosophical context, relating Rortyan themes to the work of his many influences, which range the gamut from the classical pragmatists - Peirce, James, and Dewey - to Continental thinkers - Hegel, Nietzsche, Heidegger, and their postmodernist successors - to analytic philosophers, including Wittgenstein, Sellars, Quine, Davidson, and, more surprisingly, Carnap. What emerges is a nuanced vision of Rorty's multifarious intellectual project, and it is an impressive feat that Calcaterra accomplishes this in a fairly slim volume.

2 Coming to Rorty as a political theorist, I was especially intrigued by Calcaterra's treatment of his political thought. This might be surprising, since she announces in the preface that she doesn't examine this aspect of his work (Calcaterra 2019: xiv)! In truth, she does discuss Rorty's conception of liberalism, though she refrains from analyzing his professed commitment to egalitarian social democracy. On one hand, this is a perfectly legitimate authorial choice to make; no single volume can explore every aspect of Rorty's thought, so it is inevitable that some topics will be left out. As her title indicates, Calcaterra focuses on Rorty's conception of contingency - his "contingentism," which insists that all of our descriptions of the world are in some sense optional - and its (fraught) relationship to normativity. On the other hand, Calcaterra knows that an array of critics on the Left, from Deweyan democrats to post- 
Marxist radicals, find Rorty's politics complacent and retrograde. Since Calcaterra is so perceptive in her examination of Rorty's contingentism, and because his political ideal, which he famously dubs "liberal utopia," is the pragmatic, normative counterpart to his contingentism, I found myself wanting to hear her thoughts about the political controversy that followed him.

In a classic 1994 article, Richard Shusterman suggests that Rorty's contingentism is concomitant to an emphasis on negative liberty that is in tension with his advocacy of an old Left, social democratic politics. ${ }^{1}$ This tension is what many of his leftist critics are ultimately reacting to. Calcaterra discusses one of these critics, feminist philosopher Nancy Fraser, and hints that both Fraser and John Dewey offer more theoretical resources than Rorty to resist and criticize what Fraser deems neoliberal individualism (Calcaterra 2019: 107-8). Further, in one of the most intriguing discussions in the book, Calcaterra argues that Rorty offers a "new pragmatic anthropology" that conceives of human beings as linguistic agents whose most important feature is that we can use language as a "tool of tools" to create novel purposes and ways of being (Calcaterra 2019: 108-28). In this she agrees with Robert Brandom's interpretation of Rorty's liberalism, which in turn has affinities with Shusterman's argument that Rorty, perhaps in spite of his avowed policy preferences, emphasizes an individualistic negative liberty that arguably renders Rorty's liberalism akin to a pragmatic, free-market, classical liberalism. In other words, on this reading, Fraser is right: Rorty's political thought does not support a deeply egalitarian social democracy. His enthusiastic endorsement of radical contingentism, aestheticized individual self-creation, and of the radical pluralism that results from our experimental uses of negative liberty in the private sphere is ultimately incompatible with the egalitarianism espoused by the academic Left. Obviously, Rorty is a far cry from a social Darwinist, but then even the modern classical liberalism of F.A. Hayek insists upon a humane welfare safety net. Is Rorty best read as a crypto-Hayekian? Perhaps we should ignore Rorty's self-identification with the old Left and recognize that his intense commitment to individual liberty and the dynamic cultural innovation that it produces means he is better characterized as a pragmatic classical liberal.

I attempt to sketch this proposition below and would be interested to know what Calcaterra might make of it because she is that rarest of things: a careful and fair reader of Rorty's work. But I will build to this sketch by first discussing one of Calcaterra's many interesting criticisms of Rorty. She suggests that Rorty's conception of contingentism could have been rendered more plausible if he had been more attentive to Peirce's related concept of "tychism." Tychism, Calcaterra tells us, is "the ontological-metaphysical hypothesis according to which the occurrence of chance is a real factor among natural phenomena" (Calcaterra 2019: 123). Rorty, however, tends to be dismissive of Peirce, and Calcaterra surmises that Rorty rejects tychism because his neopragmatist contingentism prevents him from invoking ontological-metaphysical hypotheses that purport to identify fundamental, and thus privileged, characteristics of reality. Calcaterra observes that "Rorty prohibits himself from using the vocabulary of metaphysics and he certainly has good reasons for taking such a stance, since he identifies metaphysics with foundationalism and authoritarianism" (ibid.). She poses the pertinent question, however, of whether "Rorty's contingentism is itself a metaphysical construction," and remarks a consideration of tychism might have induced him to address this crucial issue. As she puts it, "Peirce's tychism might provide an interesting theoretical integration of the issues at stake in the ethical claim 
accompanying Rorty's critique of the absolutistic implication of modern metaphysics" (ibid.). Calcaterra insists that there is nothing authoritarian about the metaphysics of tychism; embracing something like it may have saved Rorty from accusations that he is confused about the metaphysical nature of contingency.

Interestingly, Rorty does refer to tychism in at least one place in his opus. In "The Continuity Between the Enlightenment and 'Postmodernism'," Rorty writes:

The attempt to synthesize Hegel and Darwin into a syncretic evolutionary and historicist world-view led philosophers away from [the historical determinism of] Marx and Spencer in the direction of what Peirce called "tychism" - an emphasis on the role of chance in determining the course of both biological and cultural evolution [...] On a tychistic view of evolution, you cannot extrapolate from the past to the future. You cannot do with History what the Enlightenment tried to do with Nature. You cannot get it right, once and for all. All you can do is use the tools available in the present to make the future different than it might have been. You can practice utopian politics but you cannot back up your politics by reference to what History dictates. You cannot use philosophy to underwrite your utopia [...] This de-rationalized and tychistic version of evolution produced, at the end of the nineteenth century, the great forerunner of "postmodernism": Nietzsche. It also produced the founders of American pragmatism: James and Dewey. (Rorty 2001: 30)

6 To Peirce fans, Rorty's quick reference to tychism, positive though it is, will be seen as more of his insouciant name-dropping; indeed, he even adds insult to injury in the final sentence by conspicuously excluding Peirce from the "founders of American pragmatism!" Calcaterra would no doubt repeat that Rorty here fails to take advantage of the opportunity to further explore tychism, which could improve his contingentism.

Perhaps. Rorty, though, might have impishly replied that the title of Calcaterra's book has its terms reversed: it should be Normativity and Contingency. This is because Rorty's fundamental commitment is to his normative ideal: liberal utopia. His other commitments - to contingentism, naturalism, historicism, the "linguistic turn," and the rest of the farrago of concepts he endorses - are all in the service of his liberal politics. This leads him to make the philosophically scandalous claim, as he does in an article tellingly entitled "The Priority of Democracy to Philosophy," that we should put politics first and then tailor a philosophy to suit it (Rorty 1991: 178). He proposes contingentism because he thinks it bests suits liberal utopia. A technical, metaphysically-burdened idea like tychism, however, likely didn't strike Rorty as an auspicious intellectual tool for the advancement of his pragmatic liberalism.

"The Continuity Between the Enlightenment and 'Postmodernism"' is an excellent example of Rorty's modus operandi. In it, he urges that we separate the "philosophical Enlightenment project" - the project to identify necessary metaphysical foundations for knowledge - from the "political Enlightenment project," the practical effort to "create heaven on earth, a world without caste, class, or cruelty" (Rorty 2001: 19). The former project seeks to replace the metaphysical authority of pre-Enlightenment religion with modern science, which becomes the gold standard for what counts as genuine knowledge. Rorty, however, encourages us to dispense with metaphysical authorities altogether, and worries that the philosophical Enlightenment project leads to scientism: the privileging of science over other cultural endeavors on the grounds that it most accurately describes reality. While Rorty is a proponent of the naturalism, the Baconian technological fruits, and even of the liberal moral example provided by the practice of modern science at its best, scientism has sent philosophers scurrying to find metaphysical foundations for morality and politics that are philosophically secure 
in the context of the scientific worldview that conspicuously lacks sources of normativity. Rorty, however, thinks this scurrying is both unnecessary and also politically dangerous. It is unnecessary because "liberal democracy can get along without philosophical presuppositions" (Rorty 1991: 179). It is dangerous because, as Calcaterra notes, metaphysical foundations, which are meant to be necessary and irrefutable, are authoritarian. (The philosophical "scientific" pretensions of Soviet Marxist-Leninism, for example, leap to mind.) We should carry on the Enlightenment political project but drop the philosophical search for foundations. For Rorty, this means practicing a reformist, liberal politics, since the other major post-Enlightenment options, communism and fascism, proved abysmal failures. Moreover, eschewing metaphysical claims, we should conceive of this politics and our commitment to it as products of historical contingency, matters of chance and luck. Ideally, this frees us to be more creative in our political problem solving because the course of our politics is not predetermined by metaphysics or history. Although critics worry that "mere" contingency will not motivate people to be devoted to liberal values, Rorty insists that "a belief can still regulate action, can still be thought worth dying for, among people who are quite aware that this belief is caused by nothing deeper than contingent historical circumstance" (Rorty 1989: 189).

9 Needless to say, Rorty's gambit is controversial among philosophers, who typically accuse him of abandoning serious philosophical argument for frivolous relativism. In their view, there is little more to Rorty's liberalism than a bald claim that we should be liberals because "that's just what we do around here." His efforts to engage nonliberals amount to the exhortation, "Try liberalism, you'll like it!" This, critics claim, is all one can say if one's normative commitments are a product of historical contingency. As Calcaterra knows, however, such characterizations of Rorty's project are facile. Contingentism does not leave him so inarticulate in his promotion of liberalism. Instead, Rorty says we should persuasively describe the good features of liberal society to show how it is better than possible alternatives, how these features cohere and can be improved, and how liberal society has the resources to manage and resolve its inevitable flaws (see, e.g., Rorty 1989: 57). This includes telling Whiggish historical narratives that emphasize the progress that liberal society has made over its historical predecessors, how it has become less cruel and more inclusive. Rorty does this in "The Continuity Between the Enlightenment and 'Postmodernism'," arguing that the Enlightenment, at its best, undermined the idea that human beings must be obedient to a nonhuman authority (whose dictates are interpreted and enforced by authoritarian humans) and ushered in the potential for a mature, humanistic morality focused on democratic human flourishing. In Calcaterra's words, this is "the search for self-reliance that modernity held in jarring contrast with the foundational instances that it itself carried on through the search for extra-temporal epistemic and moral criteria" (Calcaterra 2019: 126). Ceasing the latter search will enhance our self-reliance so that we may more freely pursue a better future.

Since Rorty importantly connects liberal politics with contingentism, I was initially perplexed by Calcaterra's intention to put the political aspects of Rorty's work "deliberately aside" in order to focus on "the relationship between contingentism and normativity" (Calcaterra 2019: xiv). I found myself wondering how one could neglect Rorty's political project and do justice to this relationship. I was buoyed to discover that Calcaterra does discuss Rorty's liberalism at several points in the book, 
particularly in chapters 4-6. She clearly recognizes the import of Rorty's slogan: "Take care of freedom and truth will take care of itself." (Calcaterra 2019: 116).

Indeed, Calcaterra suggests that Rorty offers a "new pragmatic anthropology" that bolsters his post-foundationalist liberalism. She writes that this anthropology focuses "on the picture of human beings as linguistic agents: as beings who enjoy by their own nature the capability of using different vocabularies and, at the same time, of looking for languages progressively more suitable to the organization of their living situation. As a consequence, human freedom becomes an internal function of our very ability of using language for managing our own constraints and potentialities." (Calcaterra 2019: 119). This is insightful and well put, and tracks with Robert Brandom's discussion of Rorty's pragmatism. Brandom asserts that "Linguistic norms are special, in that being constrained by them gives us a distinctive sort of freedom [...] [This constraint] enables one to make and understand an indefinite number of novel claims, formulate an indefinite number of novel concepts, frame an indefinite number of novel purposes, and so on, subjecting oneself to constraint by the norms implicit in a vocabulary at the same time confers unparaleled [sic] freedom - that is, freedom to do things one could not only not do before, but could not even want to do." (Brandom 2000: 177-8).

What Brandom infers from this is provocative: "What really matters about us morally, and so ultimately, politically is not ultimately to be understood in terms of goals available from the inevitably reductive perspective of the naturalist: paradigmatically the avoidance of mammalian pain. [...] It is our capacity to transform the vocabularies in which we live and move and have our being, and so to create new ways of being (for creatures like ourselves). Our moral worth is our dignity as potential contributors to the Conversation [...] And for that reason pain, and various sorts of social and economic deprivation, have a second-hand, but nonetheless genuine moral significance." (Brandom 2000: 178). Brandom concludes that the primary goal of our political institutions should be to nurture and secure the "minimal necessary conditions of access to the Conversation" and that "our overarching public purpose should be to ensure that a hundred flowers bloom, and a hundred novel schools of thought contend" (Brandom 2000: 178-9).

In response, Rorty applauds this interpretation of pragmatic liberalism but warns that it leaves Brandom "open to the same accusations of pseudo-aristocratic condescension and ivory-tower aestheticism as are frequently leveled at me" (Rorty 2000: 189). Indeed, Brandom's discussion embraces the controversial "public-private divide" that is central to Rorty's conception of liberalism. As readers of Rorty's Contingency, Irony, and Solidarity (1989) know, Rorty suggests that liberal societies feature two primary spheres of activity that are incommensurable and cannot be reduced to one another: a public sphere where we cultivate communal solidarity and prioritize the goal of minimizing cruelty and the unnecessary suffering it produces, and a private sphere in which individuals are free to pursue their own diverse visions of the good life. Rorty's leftist critics typically charge him with focusing on the latter at the expense former. Consequently, Rorty spent the last two decades of his life deflecting accusations that his emphasis on private, Nietzschean, self-creation, carried out in the framework of liberal political community, is elitist and politically conservative. Although he endorsed the economic egalitarianism of social democracy and praised the New Left for pushing liberal politics to further diminish societal cruelty, he failed to convince his many leftist critics that he was truly committed to modern social justice. He arguably puts 
much more energy and characteristic flair into his writings about his beloved intellectual innovators and the freedom they require than he does in his bland discussions of egalitarian politics. Hence the suspicion that he is politically heretical.

Calcaterra doesn't straightforwardly reveal whether she shares this suspicion, and I assume this is what she means when she says she won't engage with Rorty's politics. She does, however, astutely discuss Rorty's liberal public-private divide. Calcaterra writes that Rorty "tries to present the cohabitation of public and private, not their absolute incommunicability: a cohabitation that lacks predetermined schemes and should be judged on the basis of the concrete improvements it will produce on both levels" (Calcaterra 2019: 106-7). This is exactly right (and missed by critics like Fraser), and the distinction between activities that are matters of public concern, and those best left to private individual choice, is itself subject to debate and evolution as we use our freedom to experiment with new activities, and publicly discuss whether they might need to be regulated if they produce any harms. As Rorty admits, he's really just updating J.S. Mill (Rorty 2010).

Calcaterra also presents the leftist critique of Rorty's liberalism by contrasting him with Nancy Fraser and John Dewey. She writes, "Similarly to Nancy Fraser, Dewey claims a radical democracy is able to contrast with the most disturbing consequences of American capitalism" (Calcaterra 2019: 108). She suggests that Dewey would have sympathized with Fraser's concern that, "In a cruel twist of fate, I fear that the movement for women's liberation has become entangled in a dangerous liaison with neoliberal efforts to build a free-market society. That would explain how it came to pass that feminist ideas that once formed part of a radical worldview are increasingly expressed in individualistic terms." (Calcaterra 2019: 108, quoting Fraser 2013). For Fraser, Rorty's liberal individualism is indicative of the problem (see Fraser 1989: 93-111). It is true that Rorty shows little interest in "radical democracy," and while he would resist the accusation that he is complicit in neoliberal efforts to build a freemarket society, this is Fraser's charge. While Calcaterra does not express agreement with this, neither does she defend Rorty from it.

I want to suggest that he doesn't need defending because he shouldn't resist the accusation. Fraser is correct insofar as she finds that Rorty's emphasis on the negative liberty of individuals in the private sphere dovetails with a version of free-market classical liberalism. (I purposely avoid the Fraser's term, "neoliberalism"; it has too much vagueness and baggage.) Shusterman highlights Rorty's commitment to negative liberty and, like Calcaterra, contrasts it with Dewey's less individualistic, more positive freedom-oriented democratic theory. Moreover, Shusterman argues that a source of this difference comes from Rorty's more radical contingentism. Shusterman observes:

If Dewey's utopia “aims to harmonize the development of each individual with the maintenance of a social state in which the activities of one will contribute to the good of all the others" so that very different individual self-fulfillments can contribute to "a fund of shared values," Rorty more modestly and negatively wants to leave individuals to their own devices, whatever (and however meager) they be. He sees "the aim of a just and free society as letting its citizens be as privatistic, 'irrationalist,' and aestheticist as they please so long as they do it on their own time - causing no harm to others," and as trying "to equalize opportunities for selfcreation and then leave people alone to use or neglect their opportunities." (Shusterman 1994: 396; citations omitted) 
Shusterman proceeds to illuminate the contrast between the Hegelian, neo-republican Dewey and the neo-Nietzschean, classically liberal Rorty. Dewey insists that democratic political participation is necessary for his ethical ideal of "growth." As Shusterman elaborates, Dewey and Rorty both value the development of the individuality of every member of a community, but in Dewey's democratic vision there is simply more harmony and a more obvious link between ethical individuality and the common good. His analogizing of democratic politics to the scientific method is illustrative: ideally, for Dewey, democratic politics proceeds like debates among scientists in the process of experimental problem solving. But, as critics are quick to point out, the analogy is weak: democratic debates over the common good are not like the debates among specially-trained experts who mostly agree about what problems they are working on and what counts as solutions. There simply isn't the same degree of practical homogeneity or unity of purpose in a modern democratic community as there is in the scientific community. Critics infer that Deweyan democracy cannot tolerate and is therefore oppressive of the deep ethical pluralism that modern democracies contain, and which Rorty's liberalism seeks to foster (see, e.g., Talisse 2007: 27-53).

In contrast with Dewey's more organic conception of democratic community that, as Shusterman and Calcaterra note, opposes a public-private dichotomy, Rorty argues "that self-realization must therefore lie in maximizing one's distinctive idiosyncrasy by highlighting the particular contingent differences that distinguish us from other members of our community and by confining our efforts of self-creation to the private sphere, [...]" (Shusterman 1994: 400). Shusterman concludes, "To sum up, Rorty's radicalization of contingency engenders a far more narrowly individualistic idea of self-realization than Dewey's" (Shusterman 1994: 399).

These points form the beginning of larger defense of Rorty as a pragmatic classical liberal that cannot be carried out here. But a précis might go something like this: according to Calcaterra and Brandom's interpretation of Rorty's pragmatic liberalism, freedom is a matter of individuals being able to engage in experimental linguistic behavior; this is why Rorty says that what matters for freedom is that you are able to express yourself without getting hurt (Rorty 1989: 176). While severe social and economic deprivation can diminish a person's capacity as a "linguistic agent," it is not clear that the high degree of economic egalitarianism, produced through high levels of redistribution, that leftist politics typically demands is necessary to enable all citizens to be free. If, in Brandom's phrase, the "minimal necessary conditions" for freedom simply entail a reasonable welfare safety net and a good school system, in addition to a few other public goods accepted by classical liberals, like internal and external security to ensure our negative rights, then it would seem that Rorty's liberalism is simpatico with a version of classical liberalism like Hayek's, with its robust, experimental market freedom in the private sphere.

Indeed, it's the corollary of minimizing economic redistribution that Rorty's liberalism arguably requires: a greater range of individual experiments can take place in the private sphere because of the greater economic inequality that a classical liberal society contains relative to a more highly egalitarian society, which is by definition more economically homogeneous. There is a tradeoff between Rorty's two values that he never fully grapples with in its economic dimension: between egalitarian economic public policy, and the diversity of life experiments in the private realm. Oversimplifying the mind-bogglingly complex economic ecosystem, we can say that if 
we narrow the range of economic inequality in a society through redistribution from rich to poor, we prevent the experimentation that would have taken place outside of the egalitarian range. Egalitarians would claim that this is fine and just: even if we appreciated the life experiments of the relatively rich (there is, of course, a long tradition on the Left to despise the values and lives of the bourgeoisie), the lives of the relatively poor lived below the egalitarian range should not be permitted in a just society (at least in the absence of a meaningfully free choice to live below the range). But if Rorty is committed to letting more flowers bloom, shouldn't he desire the wider, more economically inegalitarian range of experiments, provided that an adequate, cruelty-reducing, welfare safety net is in place? This would seem to be consistent with Brandom's suggestion that the latter is of "second-hand" if still genuine importance relative to (negative) linguistic freedom. As we saw above, Rorty writes, in a very unDeweyan line, that "the aim of a just society" is "letting its citizens be as privatistic, 'irrationalist,' and aestheticist as they please so long as they do it on their own time causing no harm to others and using no resources needed by those less advantaged" (Rorty 1989: xiv). Rorty here comes close to recognizing the tension and tradeoff. I have applied the slippery modifiers "reasonable" and "adequate" to "welfare safety net" above, and Rorty would likely protest that for him this does mean very high, leftist levels of redistribution. But given his passionate emphasis on Berlinian negative liberty and pluralism in the private sphere, it seems plausible to interpret him as a pragmatic classical liberal.

\section{BIBLIOGRAPHY}

BRANDOM Robert, (2000), "Vocabularies of Pragmatism: Synthesizing Naturalism and Historicism," in Id. (ed.), Rorty and His Critics, Oxford, Blackwell, 156-83.

CALCATERRA Rosa M., (2019), Contingency and Normativity: The Challenges of Richard Rorty, Leiden, Boston, Brill Rodopi.

FRASER Nancy, (1989), Unruly Practices: Power, Discourse, and Gender in Contemporary Social Theory, Minneapolis, University of Minnesota Press.

FRASER Nancy, (2013), “How Feminism Became Capitalism's Handmaiden - And How to Reclaim

It," The Guardian, October 14. Online: [https://www.theguardian.com/commentisfree/2013/oct/

14/feminism-capitalist-handmaiden-neoliberal].

RORTY Richard, (1989), Contingency, Irony, and Solidarity, Cambridge, Cambridge University Press.

RORTY Richard, (1991), Objectivity, Relativism, and Truth, Cambridge, Cambridge University Press.

RORTY Richard, (2000), "Response to Brandom," in Robert Brandom (ed.), Rorty and His Critics, Oxford, Blackwell, 183-90.

RORTY Richard, (2001), “The Continuity Between the Enlightenment and 'Postmodernism', in Keith Michael Baker \& Peter Hanns Reill (eds.), What's Left of Enlightenment: A Postmodern Question, Stanford, Ca., Stanford University Press. 
RORTY Richard, (2010), "Reply to Schneewind," in Randall E. Auxier \& Lewis Edwin Hahn (eds.), The Philosophy of Richard Rorty, Chicago, Open Court, 506-8.

SHUSTERMAn Richard, (1994), “Pragmatism and Liberalism Between Dewey and Rorty," Political Theory, 22 (3), 391-413.

TALISSE Robert B., (2007), A Pragmatist Philosophy of Democracy, New York, Routledge.

WESTBROOK Robert B., (2005), Democratic Hope: Pragmatism and the Politics of Truth, Ithaca, Ny., Cornell University Press.

\section{NOTES}

1. Robert Westbrook concurs, writing that "Rorty's politics is centered on negative liberty, 'our ability to leave people alone"” (Westbrook 2005: 208).

\section{AUTHOR}

\section{WILLIAM M. CURTIS}

University of Portland

curtisw[at]up.edu 